\title{
Phytopathology
}

\section{The Big Rust and the Red Queen: Long-Term Perspectives on Coffee Rust Research}

\author{
Stuart McCook and John Vandermeer
}

First author: History Department, University of Guelph, Ontario, Canada; and second author: Department of Ecology and Evolutionary Biology, University of Michigan, Ann Arbor.

Accepted for publication 24 May 2015.

\begin{abstract}
McCook, S., and Vandermeer, J. 2015. The Big Rust and the Red Queen: Long-term perspectives on coffee rust research. Phytopathology 105:1164-1173.

Since 2008, there has been a cluster of outbreaks of the coffee rust (Hemileia vastatrix) across the coffee-growing regions of the Americas, which have been collectively described as the Big Rust. These outbreaks have caused significant hardship to coffee producers and laborers. This essay situates the Big Rust in a broader historical context. Over the past two centuries, coffee farmers have had to deal with the "curse of the Red Queen"- the need to constantly innovate in the face of an increasing range of threats, which includes the rust. Over the 20th century, particularly after World War II, national governments and international organizations developed a network of national, regional, and international coffee research institutions. These public institutions played a vital role in helping coffee farmers manage the rust. Coffee farmers have pursued four major strategies for managing the rust: bioprospecting for resistant coffee plants, breeding resistant coffee plants, chemical control, and agroecological control. Currently, the main challenge for researchers is to develop rust control strategies that are both ecologically and economically viable for coffee farmers, in the context of a volatile, deregulated coffee industry and the emergent challenges of climate change.
\end{abstract}

In 1869 , the first recorded epidemic of the coffee rust (caused by the fungus Hemileia vastatrix) broke out in Ceylon (now Sri Lanka). Between 1869 and 1985, the disease spread from Ceylon (now Sri Lanka) to virtually every coffee-growing region in the world. With the help of scientists, coffee farmers developed tools and strategies to manage the disease and adapt their farms to the epidemic. By the 1990s, it seemed that the disease was largely under control, a manageable inconvenience for coffee farmers. In the first decade of the 2000s, however, a serious cluster of outbreaks - which the biologist Peter Baker has called "the Big Rust"-broke out across the Americas, encompassing an area bounded by Mexico in the north, Peru in the South, and the Dominican Republic in the east (Baker 2014). Beginning in 2008, rust outbreaks began to cause severe losses in Colombia, ultimately leading to a (temporary) $31 \%$ drop in production from 2007 levels, although production has since recovered (Avelino et al. 2015). The epidemic's focus moved northward in 2012/2013, causing significant losses in parts of Central America and Mexico. Its focus now seems to be moving southward; in 2014/2015 severe losses are being reported in Ecuador and Peru. The fungus also appeared to be adapting to different climates. Intense outbreaks were recorded in high-

Corresponding author: S. McCook; E-mail address: stuart.mccook@uoguelph.ca

http://dx.doi.org/10.1094/PHYTO-04-15-0085-RVW

(C) 2015 The American Phytopathological Society altitude coffee farms (above 1,000 m), areas where the rust's impact has previously been limited (Avelino et al. 2015). It also caused unusually high primary losses-where the epidemic affects the current year's production. Normally, the coffee rust causes high secondary losses, affecting production in the following year (Avelino et al. 2015) (Fig. 1).

Between 2011/2012 and 2013/2014, coffee production in Central America overall fell 17\%, from 20.2 million bags to 16.8 million bags. Losses varied significantly from one country to the next. Production in Mexico fell by $9.5 \%$, in Costa Rica by $10 \%$, in Honduras by $25 \%$, and in El Salvador by $45 \%$. The International Coffee Organization estimates that the rust has cost Central America more than \$616 million (International Coffee Organization 2014). The losses in production were compounded by a sharp fall in coffee prices, meaning that farmers earned significantly less for their reduced harvest. Between March 2011 and December 2013, indicator prices paid to coffee growers fell by half (International Coffee Organization 2015). The total export value of coffee from Central America dropped $50 \%$ in just 2 years. On top of this, coffee farmers have been caught in a price/cost squeeze: just when their income from coffee was falling, the costs of critical inputs-fertilizers and fungicides-was rising. Day laborers have also suffered: the demand for day laborers on coffee farms dropped by as much as a third. The wages of the laborers who could find employment dropped by as much as $20 \%$. These crises together contributed to food stress and 
food insecurity in parts of Guatemala and Honduras. A deeper humanitarian crisis was forestalled by quick action from the World Food Program, international agencies, and smaller nongovernmental organizations, although income and wages in the coffee sector remain low (Avelino et al. 2015; FEWS NET 2014a, 2014b).

The "Big Rust" was-like all natural disasters-not simply a random accident of nature. It was caused by a historically specific conjuncture of natural and social processes that made Latin America's coffee landscapes vulnerable to such an event (Oliver-Smith 1996). Some of the new natural processes include changing meteorological patterns, changes in the rust fungus itself, and changes in the ecology of coffee farms. The outbreak in Colombia seems to have been triggered by unusually high rainfalls, while the outbreaks in Central America may have been the result of irregular rainfall patterns and a warming in minimum temperatures, although there is no clear consensus on this (Baker 2014). Recent research suggests that both the Colombian and Central American epidemics were also associated with a reduction in diurnal temperature range, which shortened the disease's latency period. The shortened latency period might help explain how the outbreak produced unusually high primary losses. The changing temperature range might also explain why the outbreaks began having larger impacts at higher altitudes (Avelino et al. 2015). Initially, there was some speculation that the epidemic might have been caused by the emergence of a new, more aggressive race of rust, but this hypothesis has not yet been confirmed (Avelino et al. 2015; Buriticá Céspedes 2010). Elsewhere it has been suggested that ecological forces associated with the disease such as lack of control by natural enemies (Vandermeer et al. 2009; 2014) or landscape changes in vegetation structure (Avelino et al. 2012, Vandermeer and Rohani 2014) might be the cause.

The Big Rust also had important underlying social and technical causes. At the deepest level, the outbreak was, according to one report, a "symptom of deeper problems of coffee cultivation in the region, such as inadequate crop management, neglected and ageing coffee farms, [and the continued planting of] susceptible varieties, among others" (Promecafé 2013). These "deeper problems" were not the products of complacency or indifference on the part of coffee farmers. Instead, they were the product of a historical conjuncture in the global coffee economy since 1990, during which coffee production has skyrocketed, prices have entered a phase of unprecedented volatility, and in which many key institutions that have supported coffee farmers have been weakened or dismantled altogether (Fridell 2014a; Samper Kutschbach and Topik 2012; Topik et al. 2010). These changes have made it more difficult for coffee farmers - and coffee researchers-to manage the disease as effectively as they had before 1990 .
Baker (2014) and Avelino et al. (2015) have provided excellent overviews of the Big Rust. This paper situates the Big Rust in the broader historical context of the coffee rust since 1869. It links the historical development of the coffee rust, and of rust research, to the historical evolution of the global coffee industry. Coffee, like many other crops, has faced an increasing range of biological and environmental challenges over the past 150 years, of which the rust is one of the most serious (Ploetz 2007). Coffee farmers have faced what the economic historians Olmstead and Rhode describe as the "curse of the Red Queen." Like the Red Queen in Lewis Carroll's Through the Looking Glass, coffee farmers have had to run fast just to stay in one spot (Olmstead and Rhode 2008). Over the 20th century, coffee farmers have come to depend on a steady stream of biological innovations in order to increase - or even to maintain — productivity and quality in the coffee industry. These vital innovations have been produced almost entirely by scientists working at public or semipublic research centers. Coffee researchers are pursuing a moving target; not only is the rust fungus evolving, but so too are global environments, and the global coffee economy. It has become ever costlier for farmers to continue producing coffee (Samper Kutschbach 2003), and also for institutions to conduct the research essential to sustain coffee production.

\section{RUST AND THE RED QUEEN: EPIDEMICS, ECONOMY, AND SCIENCE SINCE 1870}

There have been three major phases in the history of coffee rust and rust research, which correspond to broader historical processes. The first phase - the colonial phase-lasted roughly from 1869 to 1945; the developmentalist phase lasted from about 1945 to 1990; and the current "neoliberal" phase began in 1990. These phases reflect evolving global political and economic paradigms of development, which in turn shaped the dynamics of the global coffee economy. They also reflect the evolving scientific understanding of crops and crop disease, which have changed significantly since the mid-19th century. Each coffee-producing region has, however, experienced these global processes in distinct ways. As we shall see, local ecological and social dynamics have also played a key role in shaping the rust outbreaks, and how people responded to them.

For much of the long 19th century, the global coffee industry was shaped by liberal paradigms of export-led development. European powers promoted coffee cultivation in their African, Asian, and Pacific colonies as a way of making the colonial enterprise profitable. Many of the newly independent nations of Latin America also turned to coffee cultivation, as a way of earning hard currency for development. For much of the 19th century, global demand for coffee-in Europe and, above all, the United States-grew faster than did the global supply
FIGURE 1

The "Big Rust" in Latin America since 2008.

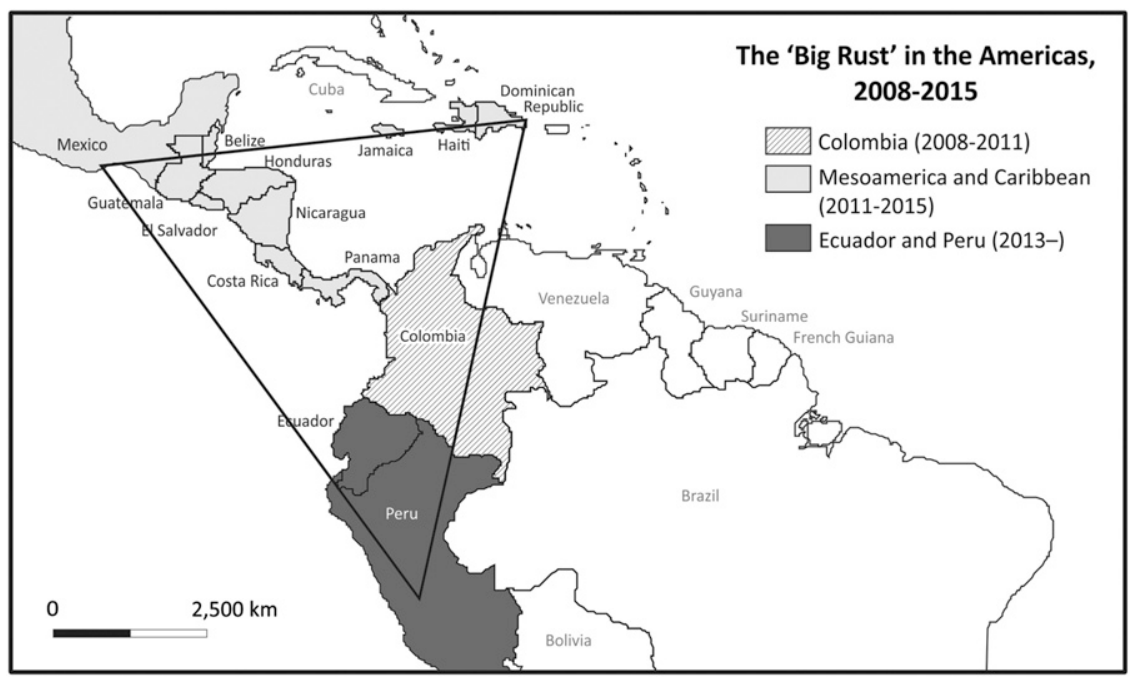


(Pendergrast 1999). Planters across the globe cleared tropical forests, often to make way for extensive coffee monocultures that, in retrospect, were highly vulnerable to epidemics such as the rust. Between 1869 and 1930, the coffee rust spread from Ceylon across the rim of the Indian Ocean Basin, extending from the eastern coast of Africa to the archipelagos of the western Pacific. It spread by means both natural and human - by winds and by migrant laborers and planters traveling the new steamship routes. The epidemic left "Arabica graveyards" in India, the Dutch East Indies, the Philippines, and many smaller regions. It also sharply restricted the spread of Arabica cultivation in East Africa (McCook 2006).

Coffee planters sought the help of scientists to help understand the dynamics of this new disease and (ideally) to develop tools to manage it. The imperial botanical gardens in the region focused mostly on bioprospecting: collecting, disseminating, and acclimatizing new varieties and species. In the 1870 s, scientists at the Royal Botanic Garden at Kew conducted a global survey of coffee-growing regions, to determine where the rust was present. Later in the 19th century, the Royal Botanic Garden coordinated efforts to circulate cultivars and species of coffee to infected areas, in a largely futile quest to find resistant varieties. The scientists at the Royal Botanic Garden in Peradeniya, Ceylon, did some fieldwork on the rust through the 1870s. It wasn't until 1880 that the imperial government sent just a single botanist-Harry Marshall Ward-to study the rust in Ceylon, and even then they just gave him a 2-year contract. Ward conducted pioneering work on the life cycle and ecology of the rust, but could not offer Ceylon's coffee planters suggestions about any viable means to control it. In the early 1900s, the coffee research station in Java, in the Dutch East Indies, conducted pioneering work on the rust and on the development of commercially viable strains of Coffea canephora, especially the variety known commercially as Robusta coffee (Cramer 1957; McCook 2006). But apart from these examples, there was limited publicly supported research in the rust-affected areas, and coffee farmers were left to their own devices. They experimented with newly developed fungicides such as the Bordeaux mixture and, in India, identified some varieties of Arabica that seemed to show resistance to the rust. But solutions to the coffee rust remained elusive.

For many planters the only viable response was to abandon coffee cultivation altogether. In Ceylon, coffee planters had, by the late 1880 s, switched from cultivating coffee to cultivating tea (Webb 2002). Incidentally, the collapse of Ceylon's coffee industry does not explain why the British drink tea, as some sources claim (Carefoot and Sprott 1967; Scheffer 1997). British coffee consumption remained constant-between 30 and 32 million lbs. annually-through the years when the rust destroyed Ceylon's coffee industry (Simmonds 1889). Britain had never depended solely upon Ceylon for coffee, and British coffee traders likely made up any shortfall from Ceylon by purchasing coffee from other coffee-producing regions. Elsewhere in the Indian Ocean Basin, such as the Dutch East Indies and Malaysia, producers switched from cultivating coffee to rubber, taking advantage of the growing demand for rubber in industrializing Europe and North America. The rust contributed to the relative and absolute decline of coffee cultivation in Africa, Asia, and the Pacific. In the early 19th century, those regions had accounted for about a third of global coffee production; a century later, they accounted for less than 5\% (Clarence-Smith 2003).

The second phase - the developmentalist phase-lasted from the mid-20th century to the early 1990s, a period roughly lasting from the end of World War II to the end of the Cold War. For much of this period (from the early 1960s to 1989), the global coffee trade was governed by the International Coffee Agreement (ICA). To ensure that coffee prices remained reasonably high and stable, the ICA set export quotas for each producing nation (Samper Kutschbach and Topik 2012). States took a more active role in promoting national development than they had in the colonial phase. Development programs helped guarantee social and political stability, and forestall the prospect of revolution. In the coffee sector, states provided a wide range of financial and technical support for framers. It was during these years that the rust epidemic spread to West Africa and the Americas, likely sped along by winds, and by the renewed circulation of people and plants between the world's coffee-growing regions. It was first detected in West Africa in the 1950s, although it had a small impact on the region's Robusta plants. It reached Brazil in 1970, and by the mid1980 s it had reached all of the coffee-growing regions of the Americas. The epidemic presented a significant challenge to coffee producers in the Americas, but nowhere did it cause the same kind of economic chaos and collapse that it had in Ceylon or the Dutch East Indies (McCook 2006).

Latin America's coffee farmers were more resilient to challenges such as the rust because they could depend on new national, regional, and global coffee research institutions. Most coffee-producing nations in Latin America established national centers for coffee research. The Instituto Agronômico de Campinas (Brazil) and the Centro Nacional de Investigaciones de Café (CENICAFE) in Colombia produced globally important research on coffee rust and coffee breeding. National institutions were, in turn, supported by bilateral and multilateral development agencies such as USAID and CIRAD (The French Agricultural Research Centre for International Development). Coffee researchers were also connected to regional research centers, such as the Inter-American Institute of Agricultural Sciences (IICA, founded in 1942), and the Program for the Protection and Modernization of Coffee (PROMECAFE, founded in 1978). A global center for coffee rust research-The Coffee Rusts Research Center, better known by its Portuguese acronym CIFC — was established near Lisbon in 1955, with funding from the Portuguese government and USAID.

These institutions focused on two principal rust control strategies. The first was chemical control, which was an attractive short-term strategy. Most coffee landscapes in the Americas were at relatively high altitudes and had distinct dry seasons. This made them more suitable for chemical control than most coffee landscapes in Africa, Asia, and the Pacific. Coffee research institutions tested fungicides for their effectiveness against the rust, and also determined the optimal times for spraying and the necessary volumes of spray. The second major control strategy was breeding resistant Arabicas. Plant breeding (and plant pathology) had been transformed by the development of Mendelian genetics in the early 20th century. This provided a conceptual framework gave scientists new insights about the coffee plant and the rust fungus. It also gave them a set of tools for developing resistant coffees. CIFC, in particular, conducted pioneering work on the genetics of rust resistance, identifying physiological races of rust and helping national programs develop rust-resistant cultivars. With the support of this robust infrastructure, it seemed that the rust was becoming "just another disease" in the coffee landscapes of the Americas. But that coexistence turned out to be fragile (Avelino et al. 1999; McCook 2006; Osorto 1993).

The third phase - the neoliberal phase-began in the late 1980s with the end of the Cold War and continues to the present. The International Coffee Agreement broke down in 1989, when member states could not agree on new quotas. The United States withdrew from the International Coffee Organization in 1993 (Fridell 2014a). In the absence of quotas, global coffee production increased $42 \%$ between 1989 and 2008, leading to renewed cycles of boom and bust. Average prices for coffee in 1999 to 2003 were half of what they had been in the 5 years before the ICA ended (Samper Kutschbach and Topik 2012). At the same time, neoliberal political and economic reforms have systematically weakened the public infrastructure that had supported coffee producers for the previous half-century. For example, the Instituto Brasileiro do Café and the Instituto Mexicano del Café were closed in 1989. The position of the coffee sector within many of these nations has also diminished, as they diversified their economies away from a heavy dependence on a small handful of export crops. Nonetheless, in most of these countries coffee retains an important economic and cultural significance (Avelino et al. 2015; Samper Kutschbach and Topik 2012). To offset some of the losses of 
the 1990s, many coffee producers in Latin America have placed a renewed emphasis on quality and sustainability. This has been driven by the specialty coffee industry and nongovernmental organizations, which offer growers price premiums if they adhere to particular ethical, environmental, and quality standards (Fridell 2014a; Pendergrast 1999). On top of the economic and political challenges, climate change has emerged as a new, major environmental challenge.

The "Big Rust" is a neoliberal epidemic. It has been shaped by these larger changes in the environmental and economic conditions of coffee cultivation, which in turn shape how well individual farmers and research institutions have been able to manage the rust. In spite of many challenges, some national and regional research institutions continue to do important work. Researchers in Colombia and Central America released some of the first commercially viable rust-resistant coffees on a large scale. Other researchers conducted pioneering work on the ecology of the fungus and its reproduction. Nongovernmental organizations and private-sector organizations have started to play a greater role in sponsoring coffee research - these include the International Coffee Genome Network (founded in 2005) and World Coffee Research (founded in 2012) (Van der Vossen et al. 2015). The challenge for contemporary coffee researchers will be to develop strategies to control coffee rust that reflect the volatile economic and ecological conditions of the early 21 st century. Research into the coffee rust has followed four main lines: bioprospecting, chemical control, breeding for resistance, and agroecological control. Their relative importance has ebbed and flowed over the colonial, developmental, and neoliberal periods. In the next sections, we will briefly review the history of these four approaches to rust control and situate them in broader context.

\section{BIOPROSPECTING: THE HUNT FOR RESISTANT COFFEES}

The quest for coffee plants resistant or immune to the rust began in the very earliest days of the epidemic. The appeal of resistant plants is clear-in principle, they offered the promise of sustaining productivity in the face of the epidemic, without requiring expensive additional inputs. This quest began far in advance of any scientific theory of resistance. As the rust spread through the Indian Ocean Basin in the late 19th century, scientists and coffee planters embarked on a process of local and global bioprospecting. This marked the beginning of a sustained global circulation of coffee varietals, which continues to the present. This quest for resistance has transformed the global coffee economy by creating a new segment in the global coffee market based on Robusta coffee (C. canephora). It has also, indirectly, helped scientists develop new understanding of the genetics of rust resistance.

The global search for resistant coffees began with the outbreak of coffee rust in Ceylon. In Ceylon, Harry Marshall Ward experimented with Arabica cultivars imported from around the globe and concluded that all Arabicas must be equally susceptible to the rust. In the 1880s and 1890s, however, British planters in India found Arabicas that did show some rust resistance. The first of these was the Old Chik coffee, which was propagated and cultivated until it seemed to lose resistance to the rust. A second resistant cultivar-known as Coorg coffee-was found in the 1880s and cultivated until the 1890 s when it too seemed to lose resistance to the rust. In the coming years, planters found yet a third variety of Arabica-known as "Kent" coffee-which also resisted the rust for several decades (Wellman 1972). These small-scale varietal revolutions led to an important insight about the nature of the coffee rust fungus. Originally planters had thought that resistant Arabica varieties had somehow "lost" their resistance to the rust. But as early as 1900, the Dutch scientist P. J. S. Cramer had recognized that this apparent loss of resistance was caused by changes in the fungus, rather than by changes in the host plant itself (McCook 2011). In the 1940s, the British scientist Wilson Mayne, working in Southern India, conducted experiments with rusts collected from the Kent, Coorg, and Old Chik varieties of coffee. He discovered that some strains of coffee rust-indistinguishable under the microscope - attacked one cultivar but not others. From this, he confirmed Cramer's suspicion that the apparent "breakdown" of resistance in coffee cultivars was due to changes in the fungus, not changes in the host. In a paper published in Nature, Mayne identified two races of rust, and in later years identified two more (Mayne 1932; McCook 2011). Since then, dozens of new races have been identified.

Coffee planters and scientists also found other species of the genus Coffea that showed resistance to the rust. Before the early 19th century, the only species of coffee known to westerners was C. arabica, which was the only coffee of commerce. But as Europeans extended their colonial control over Africa in the 19th century, they identified dozens of new species of Coffea. The genus extends across equatorial Africa, from Ethiopia in the east to Liberia in the west. Most of these species were not commercially viable, but some showed at least partial resistance to the coffee rust. Some species also had other agronomic advantages over Arabica - the plants were larger, and they produced a larger volume of beans, and they were much better adapted to warmer temperatures (Charrier and Eskes 2004; Davis et al. 2006). The first new coffee species to gain any commercial importance was Liberian coffee (C. liberica), a native of West Africa. Collectors sent it to Europe in the 1870 s, and from there it was circulated globally by imperial botanical gardens and commercial nurseries. It seemed to be resistant to the rust, and between 1889 and 1900 there was a brief planting boom of Liberian coffee in the Indian Ocean Basin, especially in Malaysia and the Dutch East Indies. However, the plant faced constant problems on the market because of its distinctive taste. Later, it seemed to "lose" its resistance-likely because of a new race of rust - and by the early 1900 s most planters had abandoned it (McCook 2014).

European bioprospecting in Africa also turned up another species of coffee with commercial potential-C. canephora. As Liberian coffee succumbed to the rust in the early 1900s, some planters in the Dutch East Indies imported a variety of $C$. canephora known as Robusta coffee. It proved to be highly tolerant to the rust. Because of this, Robusta drew the attention of scientists at the coffee experiment station at Bangelan on Java (Cramer 1957). While Robusta coffee had many desirable agronomic qualities, its beans had an undesirable flavor-sometimes described as "grassy" or "harsh." Through a series of selection trials, Dutch breeders developed a neutral-tasting, commercially viable strain of Robusta. Because of its indifferent taste, it has typically commanded a much lower price than Arabica coffee. But it proved to be a viable crop in areas where it was impossible to cultivate Arabica-such as the rust-ridden tropical lowlands of the Indian Ocean Basin - and where labor and input costs were relatively low. Consuming markets also created a space for Robusta. In the United States and Europe, coffee roasters created blends of Arabica and Robusta coffees, with the Arabica providing the flavor, and the Robusta providing bulk and a lower cost. In Europe, Robustas were also commonly blended with Arabicas for espresso coffee, where Robusta helped produce the drink's distinct cremas (McCook 2013; Morris 2013). Robustas were also a key ingredient in instant coffees, which have become increasingly popular in the decades since World War II (McCook 2013; Pendergrast 1999) (Fig. 2).

By World War II, global coffee production was bifurcated. With a few significant exceptions, coffee producers in the Eastern Hemisphere cultivated Robusta, while coffee producers in the Western Hemisphere cultivated Arabica. In the first half of the century, the largest producers of Robusta included the Dutch East Indies and Uganda. In the 1950s, major new Robusta zones opened up in West Africa. More recently, Brazil and-above all-Vietnam have started cultivating Robusta on a large scale. Vietnam is now the world's second-largest coffee producer (Fridell 2014b). Robusta now accounts for more than a third of global coffee production. This plant, which was developed as a solution to 
coffee rust, has transformed the structure of global coffee production and consumption in the 20th century (McCook 2013).

\section{CHEMICAL CONTROL}

Where bioprospecting tended to be transformative, chemical control tended to be conservative. In the case of the coffee rust, at least, farmers adopted chemical controls so they could continue cultivating susceptible Arabicas. Chemical control of coffee rust has its roots in the 19th century, but farmers only adopted it widely after 1945. Before then, coffee planters in some areas had used sulfur and copper fungicides to control the rust, but they were only viable in small areas. Since World War II, global chemical corporations such as Bayer, BASF, and Syngenta have developed a wide range of fungicides, some of which have proved effective in controlling the coffee rust. Chemical control is one of the few areas of coffee rust research that has seen significant and with continuous involvement from the private sector.

Since the first outbreak of coffee rust, farmers and scientists alike have experimented with chemical controls. In the first scientific publication on the coffee rust, the British botanist Miles Berkeley suggested that planters control the outbreak by using sulfur, which had been used as a fungicide in Europe to control mildew on grape vines and fruit trees. Scientists in Ceylon thought it might also work in controlling the leaf rust. In Ceylon, the botanist Daniel Morris conducted experimental sprayings of coffee farms with black sulfur, flowers of sulfur, and Grison's mixture (sulfur and slaked lime)with mixed results (Ainsworth 1981; Berkeley 1869; Morris 1879). Later in the 19th century, coffee planters switched from sulfur fungicides to copper fungicides. The Bordeaux mixture-a mixture of copper sulfate, lime, and water-was developed in France in 1885. There, it had proved effective in controlling downy mildew of grapes and the potato blight (Ainsworth 1981). It proved equally effective against the coffee rust. It worked as a protective spray, inhibiting or preventing the germination of coffee rust spores on the underside of the leaves of the coffee plant (Haarer 1962). To be effective, copper sprays like the Bordeaux mixture (and other proprietary sprays) had to be applied at precise moments in the fungus's life cycle to ensure that the coffee leaves were coated when the spores were most likely to be germinating. They were most effective in areas with distinct wet and dry seasons, such as parts of India and Kenya. They were much less effective in areas without a distinct dry season or with irregular rainfall. According to the rust expert Frederick Wellman, such problems explained why "spraying has been a failure commercially in such countries as Ceylon, the Philippines, areas of Malaya, Bourbon, Java, Tanganyika, Uganda, and the Cameroons" (Wellman 1961).

Spraying was more successful in Latin America, where most coffee landscapes had distinct wet and dry seasons. At first, however, farmers in Latin America were slow to adopt chemical spraying, in large part because of the cost. Wellman observed that observed that "spray equipment, chemicals, and containers brought in from the temperate zone deteriorate rapidly in the tropics," and also that "shipping problems can be colossal and sometimes transport costs greatly exceed those of the spray chemicals and the machines" (Wellman and Echandi 1981). Chemical companies also developed new classes of fungicide, such as the systemic fungicides, some of which were also useful in controlling the rust (Russell 2005). These fungicides were seldom, if ever, developed to treat the coffee rust exclusively. New fungicides could cost tens (and sometimes hundreds) of millions of dollars to develop. Companies focused on developing fungicides that were effective against diseases in a wide range of crops so they would not have to recoup their research and development costs from a single industry (Russell 2005, 2006).

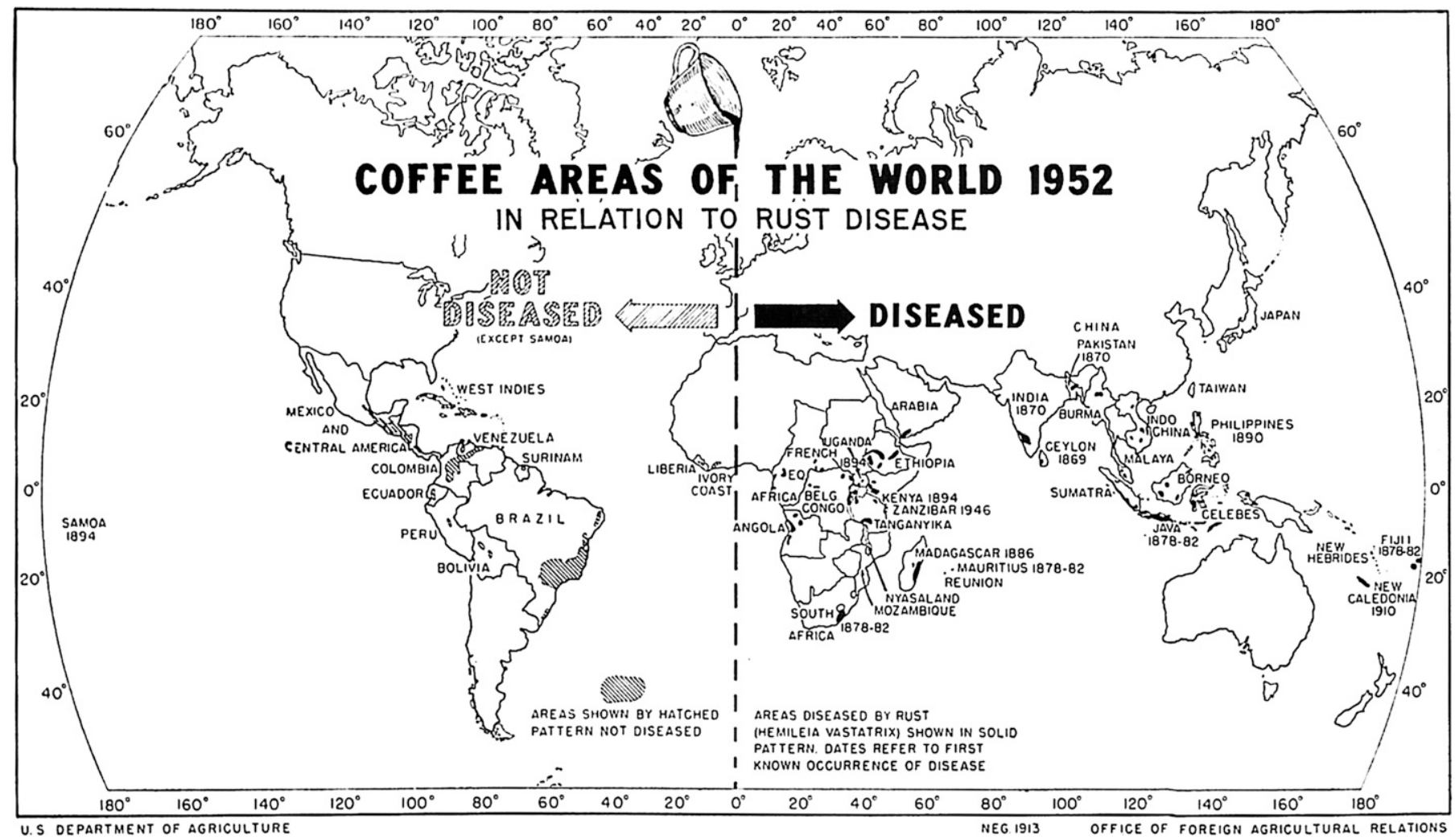

\section{FIGURE 2}

Global distribution of the coffee rust, 1952. This map also reflects the global distribution of Arabica and Robusta coffee at the time. Most countries east of the line produced Robusta, while those west of the line produced Arabica. Coffee Areas of the World in Relation to Rust Disease. 1952. Foreign Agriculture 16:160. 
Coffee farmers in Latin America gradually adopted spraying, with the support of public research institutions which determined the best timing, dose, and frequency of spray for each region. (Wrigley 1988).

Like copper fungicides, systemics could be used to prevent the fungus from infecting the leaf. Unlike copper fungicides, they could also cure infected plants. Systemic fungicides are taken up into the leaf tissue. They attack the mycelia within the leaf tissue, thus preventing further spore production (Charrier and Eskes 2004; Waller et al. 2007). Systemics could be applied in much smaller quantities and required fewer applications than did copper sprays. One study in Central America, for example, found that the triazoles required an application of just $250 \mathrm{~g}$ of active ingredient per hectare to be effective (Avelino et al. 1999). In the 1990s chemical companies released a new kind of systemic fungicide - the strobilurins - that were even more effective than the triazoles, while requiring lower doses. In practice, coffee institutes sometimes recommended that farmers apply a mix of protective (copper-based) and systemic fungicides (Rivillas Osorio et al. 2011).

While systemic fungicides could be highly effective in managing the coffee rust, they were not a panacea. If they were applied incorrectly, particularly if they were applied too late, they could contribute to the development of resistant strains of rust (Avelino et al. 1999; Ploetz 2007), and could interfere with potential natural controls (Vandermeer et al. 2009). And farmers frequently did apply chemicals incorrectly: as one study from the late 1990s observed, "it is undeniable that there is a large gulf between what is supposed to be done, and what is really done" (Avelino et al. 1999). These problems often reflected deeper problems in communication and extension work, which was necessary to ensure that farmers knew how and when to apply the chemicals effectively (Avelino et al. 1999; Muthappa et al. 1989).

Another serious problem with fungicides-which contributed directly to the Big Rust-is their cost. Coffee farmers in the Americas adopted fungicides at a historical moment when economic and technical support were generally available. Now that these supports are eroding, farmers find themselves vulnerable. According to one study from the late 1990s the "high, sometimes exaggerated cost" of agricultural chemicals "has made these products inaccessible for the majority of Central American [coffee] producers" (Avelino et al. 1999). When prices were high, farmers could afford to spray. When prices declined, they sprayed their crops less frequently, or not at all. In the early 1990s, this led to some localized rust outbreaks in Costa Rica, Nicaragua, and Honduras. The Big Rust suggests that these patterns are becoming more general. One Nicaraguan farmer observed that "most farmers simply do not have the funds to apply a full course of treatments, so they cut corners, reduce applications, buy cheap products from dubious sources and so become hostages to fortune" (Baker 2014). Planter associations in Colombia and Central America have tried to address the cost problem by providing credit to farmers, or by negotiating better prices with the agrochemical companies (Avelino et al. 2015; World Coffee Research and PROMECAFE 2013). In spite of the ongoing problems, fungicides continue to play an important role in managing the rust over the short and medium term. Over the longer term, however, coffee institutes and coffee researchers are recommending that farmers manage the rust by adopting rustresistant varieties of coffee.

\section{BREEDING: CREATING RUST-RESISTANT COFFEES}

Before the 20th century, the main tools for improving coffee were selection and bioprospecting. For thousands of years, farmers had procured and selected their own seeds. The genetic basis of cultivated Arabica was quite narrow, but occasional mutations produced new varieties of Arabica, such as Bourbon or Typica. In the late 17th century, Europeans began a continuous process of collecting and disseminating coffee varieties and species around the world. Scientists at the Dutch experiment station in Java were the first to do large-scale coffee selections, an effort that ultimately made Robusta coffee economically viable. The emergence of Mendelian genetics after 1900 gave crop breeders a new model of heredity, and therefore new tools for crop improvement. Plant breeders began to produce new coffee cultivars by cross-breeding existing cultivars and then selecting the progeny, sometimes repeating the process over several generations until they had produced a cultivar with the desired characteristics (Kloppenburg 2004). In coffee, this process could take years. The time, cost, and complexity of these programs meant that scientific coffee breeding only began in earnest during the mid-20th century, once permanent coffee research institutions had been established. At first, coffee breeders in Latin America were more concerned with improving productivity than they were with controlling rust. They developed high-yielding "dwarf" cultivars adapted for intensive production systems, which required little shade and made intensive use of fertilizers and agrochemicals. Cultivars such as Caturra (developed at Brazil's Instituto Agronômico de Campinas) were adopted widely in technified coffee farms across the Americas. While these cultivars were well adapted for intensive production, few had any significant resistance to the rust (Bertrand et al. 2012; Van der Vossen et al. 2015).

When they turned their attention to breeding for resistance, coffee breeders focused on producing a cultivar that combined the quality of Arabica coffee and the rust-resistance of Robusta coffee (Fig. 3). Attempts to cross the two species artificially met with limited success, until botanists discovered a spontaneous hybrid of Arabica and Robusta on Timor (now Timor-Leste), a tiny colonial outpost of Portugal in the Indonesian Archipelago. Between the late 1950s and the late 1960s, Portuguese planters sent several shipments of this plant to the CIFC in Lisbon for further study. Like Arabica coffee, it was a self-fertile tetraploid, which facilitated breeding programs. It also contained several important resistance genes from $C$. canephora and proved to be resistant to most known races of rust. This plant, known as the Hibrido de Timor, had little commercial value of its own, but since the 1960s it has been the foundation of breeding programs to transfer Robusta's resistance genes into Arabica coffee. The CIFC sent HdT selections to coffee research centers in the Americas (Rodrigues et al. 2004).

In the 1970s and 1980s, with the help of international and regional organizations like the CIFC and PROMECAFE, national coffee research centers in the Americas began breeding programs, many of which involved backcrossing HdT and Caturra (whose progeny were known collectively as Catimors). In the 1980s and early 1990s, institutions in Costa Rica, Honduras, and Panama all released commercially viable Catimors, including the IHCAFE 90 (developed in Honduras), and Costa Rica 95. These varieties often yielded 20 to $30 \%$ more than Caturra, but also required heavy applications of fertilizer to remain productive (Bertrand et al. 1999). Colombia has conducted some of the most important breeding programs based on HdT. Researchers at CENICAFE, the research center for Colombia's Federation of Coffee Growers, began a breeding program in the late 1960s. They crossed selections of the HdT coffees with the Caturra cultivar. In 1981, after a decade of backcrossing HdT with Caturra, CENICAFE determined that selections of the F5 generation met the requisite criteria. These selections were released as the composite, multiline Colombia variety. Like its Caturra parent, the Colombia variety was a dwarf coffee, meant to be cultivated in full sun, on technified coffee farms. It also contained five rust resistance genes from its HdT progenitor, in various combinations. This genetic diversity would, researchers expected, slow the inevitable development of resistant varieties of rust (Moreno Ruiz 2004). By the early 1990s, about a third of Colombia's coffee farms were cultivated with the Colombia variety (Buriticá Céspedes 2010; Gómez and Bustamante 2006). By 2005 almost two-thirds of Colombia's coffee farmers cultivated it, with most of the rest of the production remaining in Caturra (Duque Orrego 2005). 
By the early 2000s, however, the Colombia variety had begun to show susceptibility to new races of rust (Alvarado and Moreno 2005). Breeders at Cenicafé had, however, continued their program of developing new coffee cultivars adapted to local conditions. In 2005, they released the Castillo variety, named after a prominent Colombian coffee researcher. They released eight strains of the Castillo variety, localized to Colombia's coffee-growing regions. Like the Colombia variety, the Castillo variety was the product of crosses between Hibrido de Timor coffees and Caturra coffee, and contained a variety of horizontal and vertical resistance genes. The breeders also paid very close attention to the variety's phenotype, and to the quality of the coffee it produced. Some coffee roasters have expressed doubts about whether Castillo's cupping quality is as good as Caturra (Alvarado et al. 2005), but recent cupping trials have scored Castillo just as highly as Caturra, while recognizing differences in taste (Sheridan 2015). After the major rust outbreak of 2008, Colombia's National Federation of Coffee Growers-with the support of the national government - began a national campaign called Colombia Sin Roya (Colombia Without Rust). One of the campaign's major objectives was to encourage growers to renovate their farms with the Castillo variety. It has now been widely adopted across Colombia, and production has recovered to pre-2008 levels (Avelino et al. 2015; Van der Vossen et al. 2015).

In their analysis of the Big Rust, Avelino et al. (2015) argue convincingly that "breeding for resistance is the best long-term solution for the management of the disease." As this example shows, resistant varieties have considerable value as a tool for managing rust - in countries with a vigorous public research and extension infrastructure. All-important coffee breeding programs have been conducted by public or semipublic institutions, which have absorbed the costs of researching the plants, propagating them, and distributing them to farmers (often at or below cost). Successful renovation programs have also provided coffee farmers with access to credit and technical support necessary to renovate their farms with these improved coffees (Bertrand et al. 2012). These strategies have worked well in places like Colombia and Brazil, but have proved more of a challenge in other countries-especially in parts of Central America where coffee farmers do not have the same kind of public support (Van der Vossen et al. 2015). Recently, some researchers have argued that governments and planter associations should do more to attract private-sector investment into the development and dissemination of improved coffees. Even so, most coffee farmers would still need access to credit to buy such improved seeds (Bertrand et al. 2012). In the current neoliberal context, it remains unclear how coffee breeding and improvement can be sustained over the longer term at the levels necessary to address the myriad environmental and economic problems that the coffee industry will continue to face.

\section{AGROECOLOGICAL CONTROL}

Agroecological approaches to disease control focus on managing disease by modifying the agricultural ecosystem-for example by the use of shade, by intercropping, or through biological control (Ploetz 2007). Although the term is comparatively new, the concept is much older. Even in the initial outbreak in Ceylon, scientists have sought to understand how the ecological structure of coffee farms shaped rust outbreaks, and how farms might be structured in such a way as to limit the rust's impact. They have also done important work on the biological control of rust, seeking to understand how other organisms in the coffee ecosystem might help limit rust's impact. Some of the earliest agroecological research on coffee rust dates back to Harry Marshall Ward's pioneering research in Ceylon. Ward had been trained in the New Botany-an experimental and holistic approach to botany developed in Germany in the mid-19th century. Reflecting this approach, Ward studied the rust at both the large and small scales. He conducted controlled inoculation experiments using small, portable greenhouses, and spent a considerable amount of time studying the fungus under the microscope. He coupled his experimental work with a more ecological approach, systematically studying rust outbreaks in coffee plantations across the island (McCook 2011). Through detailed and creative research Ward determined the basics of the rust's life cycle, including the intercellular growth of mycelia, the production of haustoria, and the importance of wind dispersal (Ayres 2005).

Ward seems to have been frustrated in not being able to recommend any curative agent for the disease, but rather concentrated on what might be done to prevent the disease in the first place. He noted that topical chemical control (as in the widely used sulfur) would be effective only if it prevented spore germination in the first place, since virtually all fungal biomass was inside of the leaf tissue, never to be exposed to applied topical chemicals. He emphasized effects at the landscape level and recommended the planting of trees among coffee estates to act as windbreaks and thus reduce long-distance dispersal of the spores. He also attacked the idea of monocultures and recommended planting a mixture of coffee varieties and even other crops as intercrops. Most importantly, he recognized other fungi on leaf

\footnotetext{
FIGURE 3

A, Defoliated Arabica coffee tree in Costa Rica surrounded by rust-resistant coffees. B, Typical coffee rust lesions on leaves of a coffee plant in El Salvador, prior to premature leaf drop
}
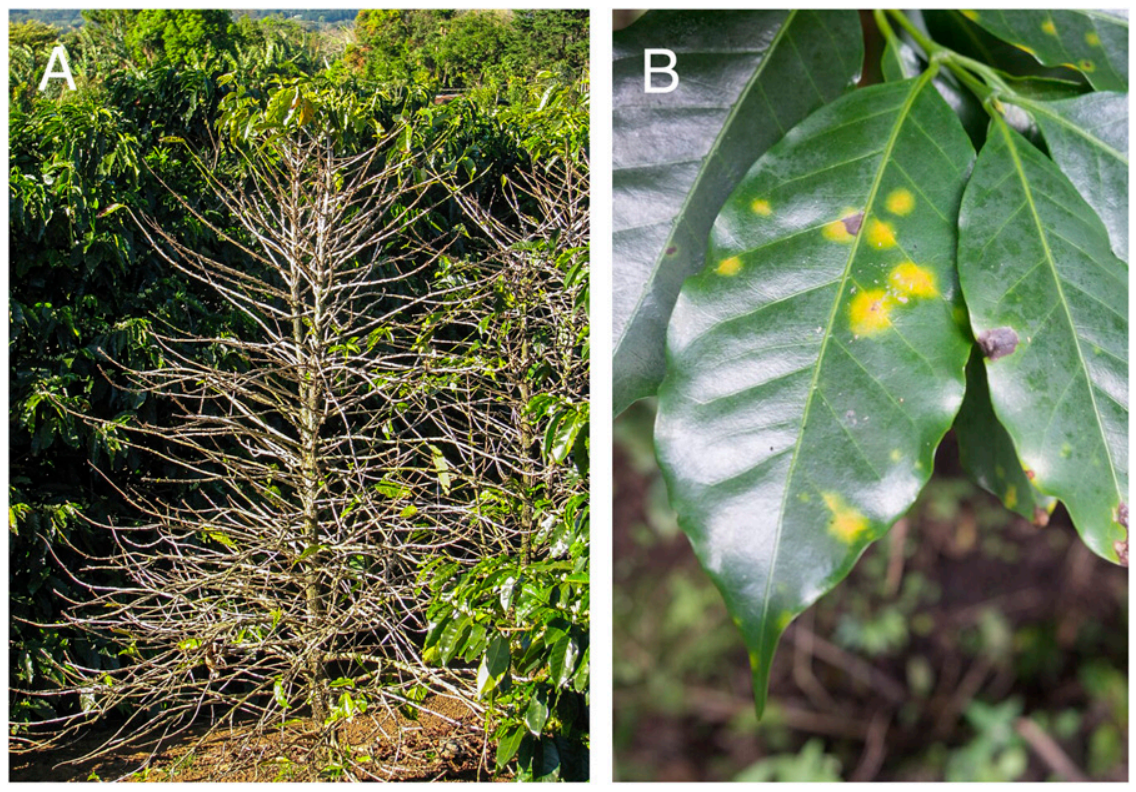
surfaces and speculated that these "...harmless fungi might influence other, pathogenic, organisms and, thus, indirectly affect the health of the leaf." (Ayres 2005). Ward's pioneering work on the rust suggested that ecological forces, generally conceived, were part of the disease's epidemiology (McCook 2011).

Before the late 20th century, however, coffee researchers devoted little attention to ecological or biological control of rust. The prevailing economic paradigms encouraged coffee farmers to intensify production so as to maximize yields (and by extension, profits). These profits could be used to pay for inputs (especially fungicides) and to subsidize the institutions that did research and development on resistant varieties. The technification of coffee after World War II, and particularly the switch to "sun" coffees such as Caturra, reflected the prevailing wisdom that shade trees promoted the development of rust. In this view, simplifying the coffee ecosystem and eliminating shade would help keep the rust under control.

Since the 1980s, however, interest in agroecological approaches to the control of the coffee rust has started to gain momentum. This reflects a number of interconnected trends, including critiques of the Green Revolution approach to agriculture, emergent concerns about biodiversity and climate change, and the growing interest in organic and certified coffee in northern markets (Fridell 2014a; Rice 2001). For example, recent research has noted that several fungi species are hyperparasites on the coffee rust. In particular, statistical evidence suggests that the hyperparasite Lecanicillium lecanii may be involved in partial control of the disease (Vandermeer et al. 2009, 2014). At least 10 species of fungi have been reported in the literature as parasites on the coffee rust (Vandermeer et al. 2014), and as noted below, several others have been encountered in Puerto Rico (J. Vandermeer, personal observation).

The particular species $L$. lecanii has a special role in that its spatial distribution is fixed by other factors in the ecosystem, making its relationship with rust incidence detectable as a spatial correlation. In particular, an important component of the general coffee agroecosystem in Mexico is a mutualistic association of the ant Azteca instabiliz, with the green coffee scale (Coccus viridis) (Perfecto and Vandermeer 2006). The key element connecting the insect pest (green coffee scale) with the pathogen (coffee rust disease) is the "white halo" fungus L. lecanii, a well-known pathogen of the green coffee scale (Easwaramoorthy and Jayaraj 1977; Reddy and Bhat 1989). It is mostly known as an entomopathogen occasionally promoted as biological control for various insect pests (Roditakis et al. 2000), but also known to attack other fungi, in particular the coffee rust (Eskes 1989; Jackson 2012; Jackson et al. 2009; Shaw 1988).

L. lecanii is only one of a potentially much larger community of fungi that are natural enemies of the coffee rust. Its importance is its spatially constrained pattern, formed by its relationship to the ant/hemipteran mutualism, that enables detection of a spatial correlation between it and the coffee rust (Jackson 2012; Jackson et al. 2009; Vandermeer et al. 2009, 2014). Frequently noted in the early literature is the presence of a dipteran larva (Mycodiplosis) (Milne 1975; Powell 1971) that, while clearly a predator on the spores of $H$. vastatrix, has rarely been thought of as an in situ controlling agent, although its potential as a manipulated biological control agent has been noted (Henk et al. 2011). It has also been suggested to be an agent of dispersal (Eskes 1989). However, one early report suggests that a couple of microhymenopteran parasitoids of Mycodiplosis might be responsible for long-distance dispersal of the rust (Crowe 1963).

Ironically, the interpretation of microclimatic influences on the rust could have been applied to potential control from mycoparasites. Removing shade from coffee farms would, on the one hand reduce the persistence of moisture thus reducing the germination rate of uredospores, but could also have reduced the viability of mycoparasites. The secondary effect of eliminating the wind-break effect of shade trees, as anticipated by Ward, would have increased the long-distance dispersal of the rust spores. Avelino et al. (2015) note that concrete empirical evidence supports both points of view, depending on other conditions (i.e., reducing shade increases windflow and thus rust infestation rates, yet shade creates the moist conditions necessary for spore germination). The question of how to properly manage shade for rust management thus remains a complicated and unsolved issue.

An important focus of recent research in coffee ecology has been associated with the nature of shade cover, emphasizing the multifunctional nature of this traditional mode of production (Perfecto and Vandermeer 2015; Vandermeer et al. 2010). The effect of shade on coffee rust is complicated and has not yet been completely worked out (Avelino et al. 2006, 2012). Certainly the microhabitat modifications implied by shade trees, from reduced wind flow to increased moisture to provisioning nitrogen, all may have major effects on the transmission of the disease and the possible effects of natural enemies, likely dependent on the nature of the shade management, are yet to be adequately addressed. These effects, as well as the continuing search for more resistant material to counteract the almost inevitable evolution of rust strains that can circumvent current resistant varieties, are likely to attract ever more attention of researchers.

\section{RUST, RESEARCH, AND THE RED QUEEN}

Over the past 150 years, the global coffee industry has become increasingly dependent on scientific research and innovation to adapt to changing ecological and economic conditions. The coffee rust has been one of the largest challenges to global coffee production. To date, coffee research has allowed producers to address the "Red Queen" problem-primarily by innovations in bioprospecting, chemical control, and breeding. These innovations have depended upon a network of national, regional, and international research institutions. These institutions are mostly public or semipublic; they work for the public good. They have absorbed most of the costs of research. They have often shared genetic and financial resources, and have coordinated their research programs (Bertrand et al. 2012; Van der Vossen et al. 2015). To date, this public innovation has allowed coffee producers to manage the rust. But coffee farmers, and the research infrastructure on which they depend, are facing new challenges.

The Big Rust is a bellwether event, revealing the serious economic, ecological, and institutional challenges the coffee industry is facing. It has shown, for example, that even small changes in weather patterns can trigger severe outbreaks of diseases and pests. It has also shown how the volatile global coffee economy makes it difficult for many coffee farmers to conduct effective rust control. Finally, it has revealed some weaknesses in the public institutional infrastructure on which the coffee industry has come to depend, although these institutions have still managed to conduct critically important work in understanding and managing the current outbreaks. In recent years, the private sector and nongovernmental organizations have started to play a more significant role in supporting research and extension. One such organization is World Coffee Research (WCR), a "non-profit, collaborative research and development program" located at the Norman Borlaug Institute at Texas A\&M University, funded by large and small coffee importers. WCR has begun a number of research projects related to the rust, including studies on best agronomic rust control practices, and a variety improvement program. Its projects are usually conducted in partnership with public institutions like PROMECAFE. Another organization, Root Capital, a nonprofit social investment fund based in the United States. In 2014 it launched, in partnership with coffee importers and the USAID, a \$23 million "Coffee Farmer Resilience Fund." This fund offers training for coffee farmers in rust-afflicted regions, and also helps finance the rehabilitation of coffee farms. But otherwise the private sector has, to date, shown little interest in coffee research. One participant in the 2013 Coffee Rust Summit complained that "a seed industry for coffee does not exist" (World Coffee Research and PROMECAFE 2013), and in a recent study Van der Vossen et al. (2015) argue that "low profitability remains a major deterrent from privatizing the multiplication and distribution of coffee cultivars," especially at 
a cost that small coffee farmers could afford. Private initiatives like these are valuable, but they are no substitute for the public sector research that has sustained the industry for more than a century.

The Big Rust has revealed the many weaknesses of coffee production in the early 21 st century. For the future, then, the challenge will be to develop lines of research that will allow coffee farmers to anticipate and adapt to the impacts of climate change, in the context of a deregulated coffee market and weakened institutional support. Research should focus on improvements that are both economically and environmentally sustainable. Chemical control will continue to have a role, especially in places where farmers have access to extension services and credit. But the current economic context, the costs of chemical control are difficult for many coffee famers to bear (Gómez and Bustamante 2006). Instead, research should focus on developing control strategies that require few expensive inputs. This includes continuing work on resistant varieties. It may also involve new forms of ecologically intensive agriculture that includes biological control and natural fungicides (Avelino et al. 2015; Bertrand et al. 2012). The status quo is not sustainable.

\section{ACKNOWLEDGMENTS}

We thank M. Puddister, cartographer at the Department of Geography, University of Guelph, for making the map of the Big Rust.

\section{LITERATURE CITED}

Ainsworth, G. C. 1981. Introduction to the History of Plant Pathology. Cambridge University Press, Cambridge.

Alvarado, G., and Moreno, L. G. 2005. Cambio de la virulencia de Hemileia vastatrix en progenies de Caturra $\times$ Híbrido de Timor. Cenicafé 56:110-126.

Alvarado, G., Posada, H. E., and Cortina, H. A. 2005. Castillo: Nueva variedad de café con resistencia a la roya. Cenicafé. Chinchina, Caldas, Colombia.

Avelino, J., Cristancho, M., Georgiou, S., Imbach, P., Aguilar, L., Bornemann, G., Läderach, P., Anzueto, F., Hruska, A. J., and Morales, C. 2015. The coffee rust crises in Colombia and Central America (2008-2013): Impacts, plausible causes and proposed solutions. Food Sec. 7:303-321.

Avelino, J., Muller, R., Eskes, A., Santacreo, R., and Holguín, F. 1999. La roya anaranjada del cafeto: Mito y realidad. Pages 193-241 in: Desafíos de la Caficultura en Centroamérica. B. Bertrand and B. Rapidel, eds. Agroamerica. CIRAD, IRD, CCCR, IICA, PROMECAFE. San Jose, Costa Rica.

Avelino, J., Romero-Gurdián, A., Cruz-Cuellar, H. F., and Declerck, F. A. J. 2012. Landscape context and scale differentially impact coffee leaf rust, coffee berry borer, and coffee root-knot nematodes. Ecol. Appl. 22: 584-596.

Avelino, J., Zelaya, H., Merlo, A., Pineda, A., Ordoñez, M., and Savary, S. 2006. The intensity of a coffee rust epidemic is dependent on production situations. Ecol. Modell. 197:431-447.

Ayres, P. G. 2005. Harry Marshall Ward and the Fungal Thread of Death. American Phytopathological Society, St. Paul, MN.

Baker, P. 2014. The "Big Rust": An update on the coffee leaf rust situation. Coffee Cocoa Int. 40:37-39.

Berkeley, M. J. 1869. Gard. Chron. 45:1157.

Bertrand, B., Aguilar, G., Santacreo, R., and Anzueto, F. 1999. El mejoramiento genético en América Central. Pages 407-456 in: Desafíos de la Caficultura en Centroamérica. B. Bertrand and B. Rapidel, eds. Agroamerica. CIRAD, IRD, CCCR, IICA, PROMECAFE. San Jose, Costa Rica.

Bertrand, B., Montagnon, C., Georget, F., Charmetant, P., and Etienne, H. 2012. Création et diffusion des variétés de caféiers Arabica: Quelles innovations variétales? Cah. Agric. 21:77-88.

Buriticá Céspedes, P. 2010. La Roya del Cafeto en Colombia: Realizaciones de Impacto Nacional e Internacional en el Siglo XX. Rev. Fac. Nac. Agron. Medellín. 63:5285-5292.

Carefoot, G. L., and Sprott, E. R. 1967. Famine on the Wind: Man's Battle Against Plant Disease. Longmans, Don Mills, Ontario.

Charrier, A., and Eskes, A. B. 2004. Botany and genetics of coffee. Pages 25-56 in: Coffee: Growing, Processing, Sustainable Production: A Guidebook for Growers, Processors, Traders and Researchers. J. N. Wintgens, ed. Wiley-VCH, Weinheim.

Clarence-Smith, W. G. 2003. The coffee crisis in Asia, Africa, and the Pacific, 1870-1914. Pages 100-119 in: The Global Coffee Economy in Africa, Asia and Latin America, 1500-1989. W. G. Clarence-Smith and S. Topik, eds. Cambridge University Press, Cambridge.
Cramer, P. J. S. 1957. A Review of Literature of Coffee Research in Indonesia. SIC Editorial, Inter-American Institute of Agricultural Sciences, Turrialba, Costa Rica.

Crowe, T. J. 1963. Possible insect vectors of the uredospores of Hemileia vastatrix in Kenya. Trans. Br. Mycol. Soc. 46:24-26.

Davis, A. P., Govaerts, R., Bridson, D. M., and Stoffelen, P. 2006. An annotated taxonomic conspectus of the genus Coffea (rubiaceae). Bot. J. Linn. Soc. 152:465-512.

Duque Orrego, H. 2005. Estudio de adopción de la variedad Colombia. Cenicafé $56: 151-174$.

Easwaramoorthy, S., and Jayaraj, S. 1977. The effect of shade on the green coffee bug, Coccus viridis (green) and its entomopathogenic fungus, Cephalosporium lecanii Zimm. J. Coffee Res. 7:111-113.

Eskes, A. B. 1989. Natural enemies and biological control. Pages 161-169 in: Coffee Rust: Epidemiology, Resistance, and Management. A. B. Eskes and A. C. Kushalappa, eds. CRC Press, Boca Raton, FL.

FEWS NET. 2014a. Coffee Producer and Laborer Income to Decline for a Second Consecutive Year. Washington, DC.

FEWS NET. 2014b. Food Security Crisis Likely Due to Coffee Rust and Drought. Washington, DC.

Fridell, G. 2014a. Coffee. Polity Press, Cambridge.

Fridell, G. 2014b. Coffee statecraft: Rethinking the global coffee crisis, 1998-2002. New Polit. Econ. 19:407-426.

Gómez, G. C., and Bustamante, A. B. 2006. Las enfermedades del café: Logros y desafíos para la caficultura colombiana del siglo XXI. Manejo Integrado Plagas Agroecol. 77:89-93.

Haarer, A. E. 1962. Modern Coffee Production. Leonard Hill, London.

Henk, D. A., Farr, D. F., and Aime, M. C. 2011. Mycodiplosis (Diptera) infestation of rust fungi is frequent, wide spread and possibly host specific. Fungal Ecol. 4:284-289.

International Coffee Organization. 2014. Annual Review 2013-14. International Coffee Organization, London.

International Coffee Organization. 2015. ICO Composite and Group Indicator Prices (annual monthly averages). International Coffee Organization, London.

Jackson, D. 2012. Indirect biological control of the coffee leaf rust, Hemileia vastatrix, by the entomogenous fungus Lecanicillium lecanii in a complex coffee agroecosystem. Biol. Control 61:89-97.

Jackson, D., Vandermeer, J., and Perfecto, I. 2009. Spatial and temporal dynamics of a fungal pathogen promote pattern formation in a tropical agroecosystem. Open Ecol. J. 2:62-73.

Kloppenburg, J. R. 2004. First the Seed: The Political Economy of Plant Biotechnology. University of Wisconsin Press, Madison, WI.

Mayne, W. W. 1932. Annual Report of the Coffee Scientific Officer, 19311932. Mysore Coffee Exp. Stn. 1-32.

McCook, S. 2006. Global Rust Belt: Hemileia vastatrix and the ecological integration of world coffee production since 1850. J. Glob. Hist. 1:177-195.

McCook, S. 2011. Managing monocultures: Coffee, the coffee rust, and the science of working landscapes. Pages 87-107 in: Knowing Global Environments: New Historical Perspectives on the Field Sciences. J. Vetter, ed. Rutgers University Press, New Brunswick, NJ.

McCook, S. 2013. The ecology of taste: Robusta coffee and the limits of the specialty revolution. Pages 248-261 in: Coffee: A Comprehensive Guide to the Bean, the Beverage, and the Industry. R. W. Thurston, J. Morris, and S. Steiman, eds. Rowman \& Littlefield, Lanham, MD.

McCook, S. 2014. Ephemeral plantations: The rise and fall of Liberian coffee, 1870-1900. Pages 85-112 in: Comparing Apples, Oranges, and Cotton: Environmental Histories of the Global Plantation. F. Uekotter, ed. Frankfurt am Main, Campus Verlag.

Milne, D. L. 1975. Coffee rust consumed by a helpful insect Mycodiplosis hemileiae. Citrus Subtrop. Fruit J. 11-12:11.

Moreno Ruiz, L. G. 2004. Obtención de variedades de café con resistencia durable a enfermedades, usando la diversidad genética como estrategia de mejoramiento. Rev. Acad. Colomb. Cienc. Exactas Físicas Nat. Bogotá. 28: 187-200.

Morris, D. (ed.) 1879. The campaign of 1879 against coffee leaf disease (Hemileia vastatrix) by the coffee planters of Ceylon. Ceylon Observer, Colombo.

Morris, J. 2013. Why espresso? Explaining changes in European coffee preferences from a production of culture perspective. Eur. Rev. Hist. 20:881-901.

Muthappa, B. N., Kannan, K., Javed, Z. U., Matiello, J. B., and Mansk, Z. 1989. Chemical control practices around the world. Pages 141-160 in: Coffee Rust: Epidemiology, Resistance, and Management. A. C. Kushalappa and A. B. Eskes, eds. CRC Press, Boca Raton, FL.

Oliver-Smith, A. 1996. Anthropological research on hazards and disasters. Annu. Rev. Anthropol. 25:303-328.

Olmstead, A. L., and Rhode, P. 2008. Creating Abundance: Biological Innovation and American Agricultural Development. Cambridge University Press, Cambridge. 
Osorto, J. J. 1993. La cooperación técnica francesa en la América Central. Pages 389-395 in: Quinzième colloque scientifique international sur le café. ASIC.

Pendergrast, M. 1999. Uncommon Grounds: The History of Coffee and How it Transformed Our World, 1st ed. Basic Books, New York.

Perfecto, I., and Vandermeer, J. 2006. The effect of an ant-hemipteran mutualism on the coffee berry borer (Hypothenemus hampei) in southern Mexico. Agric. Ecosyst. Environ. 117:218-221.

Perfecto, I., and Vandermeer, J. H. 2015. Coffee Agroecology: A New Approach to Understanding Agricultural Biodiversity, Ecosystem Services and Sustainable Development. Routledge, Taylor \& Francis Group, New York.

Ploetz, R. C. 2007. Diseases of tropical perennial crops: Challenging problems in diverse environments. Plant Dis. 91:644-663.

Powell, J. M. 1971. Additional records of mycodiplosis larvae (Diptera: Cecidomyiidae) feeding on rust fungi. Can. Plant Dis. Surv. 51:86-87.

Promecafé. 2013. Plan de acción con medidas inmediatas 2013: Programa integrado de combate a la roya del café y recuperación de la capacidad productiva en Centroamérica. Promecafé.

Reddy, K. B., and Bhat, P. K. 1989. Effect of relative humidity and temperature on biotic agents of green scale Coccus viridis (green). J. Coffee Res. 19:218-221.

Rice, R. A. 2001. Noble goals and challenging terrain: Organic and fair trade coffee movements in the global marketplace. J. Agric. Environ. Ethics 14: 39-66.

Rivillas Osorio, C. A., Giraldo Serna, C. A., Cristancho Ardila, M. A., and Gaitán Bustamante, A. L. 2011. La roya del cafeto en Colombia: Impacto, manejo y costos del control. Cenicafé, Cinchina.

Roditakis, E., Couzin, I. D., Balrow, K., Franks, N. R., and Charnley, A. K. 2000. Improving secondary pick up of insect fungal pathogen conidia by manipulating host behaviour. Ann. Appl. Biol. 137:329-335.

Rodrigues, C. J., Gonçalves, M. M., Varzea, V. M. P., de Produção, C. E., and Agrícolas, T. 2004. Importância do Hibrido de Timor para o territorio e para o melhoramento da cafeicultura mundial. Rev. Ciênc. Agrár. (Belém.) 27: 203-216.

Russell, P. E. 2005. A century of fungicide evolution. J. Agric. Sci. 143:11-25.

Russell, P. E. 2006. The development of commercial disease control. Plant Pathol. 55:585-594.

Samper Kutschbach, M. 2003. The historical construction of quality and competitiveness: A preliminary discussion of coffee commodity chains. Pages 120-153 in: The Global Coffee Economy in Africa, Asia and Latin America, 1500-1989. W. G. Clarence-Smith and S. Topik, eds. Cambridge University Press, Cambridge.
Samper Kutschbach, M., and Topik, S. 2012. Crisis y transformaciones del mundo del café: Dinámicas locales y estrategias nacionales en un periodo de adversidad e incertidumbre. Pontificia Universidad Javeriana, Bogotá.

Scheffer, R. P. 1997. The Nature of Disease in Plants. Cambridge University Press, Cambridge, New York.

Shaw, D. E. 1988. Verticillium lecanii a hyperparasite on the coffee rust pathogen in Papua New Guinea. Australas. Plant Pathol. 17:2-3.

Sheridan, M. 2015. 4 Perspectives on the Colombia Sensory Trial. CRS Coffeelands Blog, Baltimore, MD.

Simmonds, P. L. 1889. Tropical Agriculture: A Treatise on the Culture, Preparation, Commerce and Consumption of the Principal Products of the Vegetable Kingdom, 3rd ed. E. \& F. N. Spon, London, New York.

Topik, S., Talbot, J. M., and Samper, M. 2010. Introduction: Globalization, neoliberalism, and the Latin American coffee societies. Lat. Am. Perspect. 37:5-20.

Van der Vossen, H., Bertrand, B., and Charrier, A. 2015. Next generation variety development for sustainable production of arabica coffee (Coffea arabica L.): A review. Euphytica 204:243-256.

Vandermeer, J., Jackson, D., and Perfecto, I. 2014. Qualitative dynamics of the coffee rust epidemic: Educating the intuition with theoretical ecology. Bioscience 64:210-218.

Vandermeer, J., Perfecto, I., and Liere, H. 2009. Evidence for hyperparasitism of coffee rust (Hemileia vastatrix) by the entomogenous fungus, Lecanicillium lecanii, through a complex ecological web. Plant Pathol. 58:636-641.

Vandermeer, J., Perfecto, I., and Philpott, S. 2010. Ecological complexity and pest control in organic coffee production: Uncovering an autonomous ecosystem service. Bioscience 60:527-537.

Vandermeer, J., and Rohani, P. 2014. The interaction of regional and local in the dynamics of the coffee rust disease. arXiv:1407.8247 (q-bio).

Waller, J. M., Bigger, M., and Hillocks, R. J. 2007. Coffee Pests, Diseases and Their Management. CABI Publishing, Wallingford, UK; Cambridge, MA

Webb, J. L. A. 2002. Tropical Pioneers: Human Agency and Ecological Change in the Highlands of Sri Lanka, 1800-1900. Ohio University Press, Athens.

Wellman, F. 1961. Coffee: Botany, Cultivation and Utilization. Leonard Hill, London.

Wellman, F. 1972. Tropical American Plant Disease: Neotropical Phytopathology Problems. The Scarecrow Press, Metuchen, NJ.

Wellman, F. L., and Echandi, E. 1981. The Coffee Rust Situation in Latin America in 1980. Phytopathology 71:968-971.

World Coffee Research and PROMECAFE. 2013. First International Coffee Rust Summit. World Coffee Research, PROMECAFE, Guatemala.

Wrigley, G. 1988. Coffee. Wiley, New York. 